\title{
Productivity, utilization efficiency and sward targets for mixed pastures of marandugrass, forage peanut and tropical kudzu ${ }^{1}$
}

\section{Carlos Mauricio Soares de Andrade ${ }^{2}$, Rasmo Garcia ${ }^{3}$, Judson Ferreira Valentim², Odilon Gomes Pereira ${ }^{3}$}

\footnotetext{
1 Research with financial support by Fapemig and Embrapa.

2 Embrapa Acre, CP 321, 69908-970, Rio Branco, Acre.

${ }^{3}$ Departamento de Zootecnia, UFV. Scholar from CNPq.
}

\begin{abstract}
This study was carried out to evaluate the productivity and utilization efficiency of a mixed marandugrass (Brachiaria brizantha cv. Marandu), forage peanut (Arachis pintoi cv. Mandobi) and tropical kudzu (Pueraria phaseoloides) pasture, rotationally stocked at four daily forage allowance levels (6.6, 10.3, 14.3 and 17.9\% of live weight), in order to define sward management targets for these mixtures. In each stocking cycle, dry matter (DM) accumulation rates, defoliation intensity (\%), grazing depth (\%) and grazed horizon (cm) were evaluated. Sward targets were defined according to the sward condition that best conciliated the grass-legume balance and the equilibrium between forage production and utilization. Pastures submitted to higher forage allowance levels showed higher productivity, but were less efficiently utilized. It was not possible to establish sward management targets for marandugrass-tropical kudzu pastures. For marandugrass-forage peanut pastures the best sward state was set with forage allowance of $10.3 \%$ of live weight. Under rotational stocking, the following sward targets were suggested for these pastures in the Western Amazon: pre-grazing height of 30-35 cm (June to September) or 45-50 cm (October to May) and post-grazing sward height of 20-25 cm (June to September) or 25-30 cm (October to May).
\end{abstract}

Key Words: Arachis pintoi, Brachiaria brizantha, grazing management, legume, Pueraria phaseoloides, Western Amazon

\section{Introduction}

Poor grazing management is one of the main causes of low persistence of legumes in mixed swards in tropical regions (Spain, 1995; Lascano, 2000; Pereira, 2002). However, the development of grazing management strategies for grass-legume swards is not simple. Even in temperate climate regions, with longer research history on this subject, there is still much uncertainty regarding the most adequate management strategies to control the balance between plant species in mixed swards (Hodgson \& Silva, 2000). Some factors that make it difficult to define grazing management strategies in mixed swards are: a) competition between plant species; b) different responses to grazing; c) differences regarding preference by the grazing animals; and d) different climatic responses (Spain, 1995; Lascano, 2000). In the tropics, another factor that influences the establishment of management practices for mixed swards is the great diversity of forage species and morphological types, which open the possibility for a great number of binary associations. These factors indicate the need for development of specific grazing management strategies for each grass-legume association (Cruz \& Sinoquet, 1994; Thomas, 1995; Fisher et al., 1996).

Tropical kudzu (Pueraria phaseoloides) and forage peanut (Arachis pintoi) are the forage legumes most commonly used in mixed swards in the State of Acre. Tropical kudzu is a legume native from Asia, which was introduced to Brazil in 1940 for use as a cover crop in rubber and oil palm plantations in the Amazon, where it presented excellent adaptation in the different environmental conditions, becoming naturalized in the Region (Valentim \& Carneiro, 2001). This twining and climbing legume has been used in the establishment of grass-legume pastures in the State of Acre since the decade of 1980 and is actually present in more than $30 \%$ of the total pasture area. However, the intensification of cattle production systems, with the adoption of rotational stocking and the increase in stocking rates affected negatively the persistence of tropical kudzu in grass-legume swards (Valentim \& Andrade, 2005b). Forage peanut cv. Belmonte is a legume with prostrate and stoloniferous growth habit native from Brazil, which was released in 1999 in Bahia (Pereira et al., 2002) and recommended for use in Acre in 2001 (Valentim et al., 2001). 
It has been largely used in the establishment of grasslegume swards, especially during the reclamation of degraded pastures due to the syndrome of death of marandugrass (Brachiaria brizantha cv. Marandu) (Valentim \& Andrade, 2005a).

Studies of botanical composition dynamics in mixed swards of marandugrass with tropical kudzu and forage peanut showed that tropical kudzu is intolerant to more intensive grazing management systems. Conversely, forage peanut reaches a more equilibrated mixture with marandugrass when the sward is managed under pre-grazing height below $45 \mathrm{~cm}$ (Andrade et al., 2012). However, additional factors need to be considered in the definition of grazing management strategies. Therefore, this research studied the effect of forage allowance and season of the year on productivity and utilization efficiency of mixed pastures of marandugrass with the legumes tropical kudzu and forage peanut, aiming at defining sward management targets for these mixtures in the environmental conditions of the Western Brazilian Amazon. Sward targets are good practical indicators for use by farmers in the decision making process regarding grazing management, and are generally defined based on sward height (Hodgson, 1990).

\section{Material and Methods}

This experiment was carried out at the Experimental Station of Embrapa Acre (1001' 59" S and 67 $42^{\prime} 13^{\prime \prime}$ W), in Rio Branco, Acre, Brazil, between January and December 2003. The experimental area consisted of a $3,400-\mathrm{m}^{2}$ paddock with a mixed sward of $B$. brizantha cv. Marandu, P. phaseoloides and A. pintoi cv. Mandobi. The local environmental conditions were described by Andrade et al. (2012). Triple super phosphate (50 kg/ha of $\mathrm{P}_{2} \mathrm{O}_{5}$ ) was applied to the pasture at the beginning of the experiment.

The experimental area was subdivided in 12 experimental units in order to study the response of the mixed pasture to four levels of daily forage allowance (6, 10, 14 and $18 \mathrm{~kg}$ of dry mass/100 kg live weight), in a completely randomized blocks design with three replications. The levels of forage allowance effectively applied, on the average of the experimental period, were $6.6,10.3,14.3$ and $17.9 \%$ of live weight. Pastures were grazed by Nellore steers with live weight ranging from 180 to $360 \mathrm{~kg}$ under rotational stocking. Forage allowance was adjusted by varying the stocking rates in the paddocks. Stocking cycle was 28 days during the rainy season and 35 days during the dry season, with a stocking period of two days. Animals remained in the experimental units only during the stocking period, maintained in an adjacent pasture during the rest period. Overall, there were 11 stocking cycles during the experimental period. Data from each stocking cycle were grouped into the following quarters: a) January-March, full rainy season; b) April-June, transition between rainy and dry seasons; c) July-September, full dry season; and, d) October-December, beginning of the rainy season.

Sward height and forage mass were characterized immediately before and after each stocking period as described by Andrade et al. (2012). Dry matter (DM) accumulation rates $(\mathrm{kg} / \mathrm{ha} / \mathrm{day})$, in each stocking cycle, were calculated dividing total forage mass ( $\mathrm{kg} / \mathrm{ha}$ of $\mathrm{DM}$ ) accumulated during the rest period by the length of this period (days). Defoliation intensity (\%), in each stocking cycle, was calculated as the difference between pre- and post-grazing forage mass divided by pre-grazing forage mass in the respective stocking cycle. Grazed horizon (cm), in each stocking cycle, was calculated as the difference between pre- and post-grazing sward height $(\mathrm{cm})$. Grazing depth (\%) was calculated by dividing grazed horizon by the pre-grazing sward height in each of the stocking cycles.

It is important to emphasize that the technique used to calculate defoliation intensity, grazed horizon and grazing depth does not allow for the separation of the forage effectively ingested by the grazing animals from that lost in the grazing process. It is also important not to confuse defoliation intensity with efficiency of forage utilization, which in a grazing system can be defined as the proportion of gross leaf tissue production that is removed by the animals before entering the senescent state (Lemaire \& Chapman, 1996). This latter parameter obviously can only be measured by tissue flow studies. Therefore, parameters describing sward utilization in this study should be interpreted as indicators of the relative intensity of pasture utilization.

The approach used to define the sward management targets in the present study was to submit the mixed pasture to four daily forage allowance levels, under rotational stocking, in such a way as to establish different pre- and post-grazing sward conditions. Sward targets for this mixed pasture were thus established based on the sward condition that best conciliated the grass-legume balance and the equilibrium between the efficiencies of the first two steps of the animal production process under grazing: forage production and utilization. Sward targets were established for the periods of higher (October to May) and lower forage growth (June to September), similarly to what has been done in temperate countries (Hodgson, 1990; Matthews et al., 1999). Sward height (pre- and post-grazing) was the indicator 
chosen to define the sward targets recommended in this study, primarily because of its feasibility of practical application in the real conditions of commercial farms.

Pasture carrying capacity (animal units/ha) was determined according to the stocking rates applied to establish the daily forage allowance determining the ideal (critical) sward condition. Annual carrying capacity in 2003 was calculated as the average stocking rate along the year. The variation of stocking rates used in each stocking cycle allowed establishing the seasonal variation of the carrying capacity for this mixed pasture throughout the year 2003.

Analyses of variance for dry matter (DM) accumulation rate, defoliation intensity, grazed horizon and grazing depth were run according to a split-plot in time design, with main plots in a completely randomized blocks design. The four daily forage allowance levels represented main plots, with four periods (quarters) representing subplots. Significant interactions $(\mathrm{P}<0.05)$ were conveniently broken down. Variables showing significant effect of forage allowance were analyzed by simple linear regression. The choice of the best-fit equation was based on the coefficient of determination and on the level of significance of the regression coefficients. Periods were compared by the Tukey test at the $5 \%$ level.

\section{Results and Discussion}

There was no interaction ( $\mathrm{P}>0.05)$ between forage allowance and period of the year for dry matter (DM) accumulation rates. Over the experimental period, average DM accumulation rates increased linearly from 40 to $53 \mathrm{~kg} / \mathrm{ha}$ /day as forage allowance increased from 6.6 to 17.9\% LW (Figure 1A). Similar responses were observed in mixed pastures of massaigrass and forage peanut under rotational stocking in Acre (Andrade et al., 2006a) and of marandugrass and forage peanut $\mathrm{cv}$. Belmonte under continuous stocking in Paraná (Silva, 2008). As rest periods were similar for all treatments, swards managed under higher forage allowance maintained higher leaf area index (LAI) during the regrowth period, which possibly explains the higher DM accumulation rates.

There was high seasonal variation in pasture DM accumulation rates, with higher rates occurring in the period of maximum precipitation (October to March), lower rates during the dryer period of the year (July to September), and intermediate rates being observed during the transition period (April to June) (Figure 1B). The lowest DM accumulation rates (mean of $23 \mathrm{~kg} / \mathrm{ha} /$ day) were recorded in the driest month of the year (August) and the highest in December (mean of $80 \mathrm{~kg} / \mathrm{ha} /$ day). In general, annual DM production was distributed along the year as follows: 33\% in January/March, 19\% in April/June, 13\% in July/September and $35 \%$ in October/December.

Annual DM production were 14.4, 16.2, 16.7 and 19.4t/ha, from the lowest to the highest forage allowance, respectively. These values are inferior to those found by Ibrahim \& Mannetje (1998) in mixed pastures of marandugrass and A. pintoi cv. Amarillo (21.7 to $29.3 \mathrm{t} / \mathrm{ha}$ of DM), in Costa Rica, where annual rainfall is twice that recorded in Rio Branco-Acre, besides being better distributed along the year. Values of annual DM production in this study are also inferior to those reported by Andrade et al. (2006a) for swards of massaigrass and forage peanut in Acre (20.4 to $29.2 \mathrm{t} / \mathrm{ha}$ of DM). This is probably due to the higher production potential of massaigrass in comparison with marandugrass, and also due to the soil waterlogging during part of the rainy season, which affected negatively the growth of marandugrass.
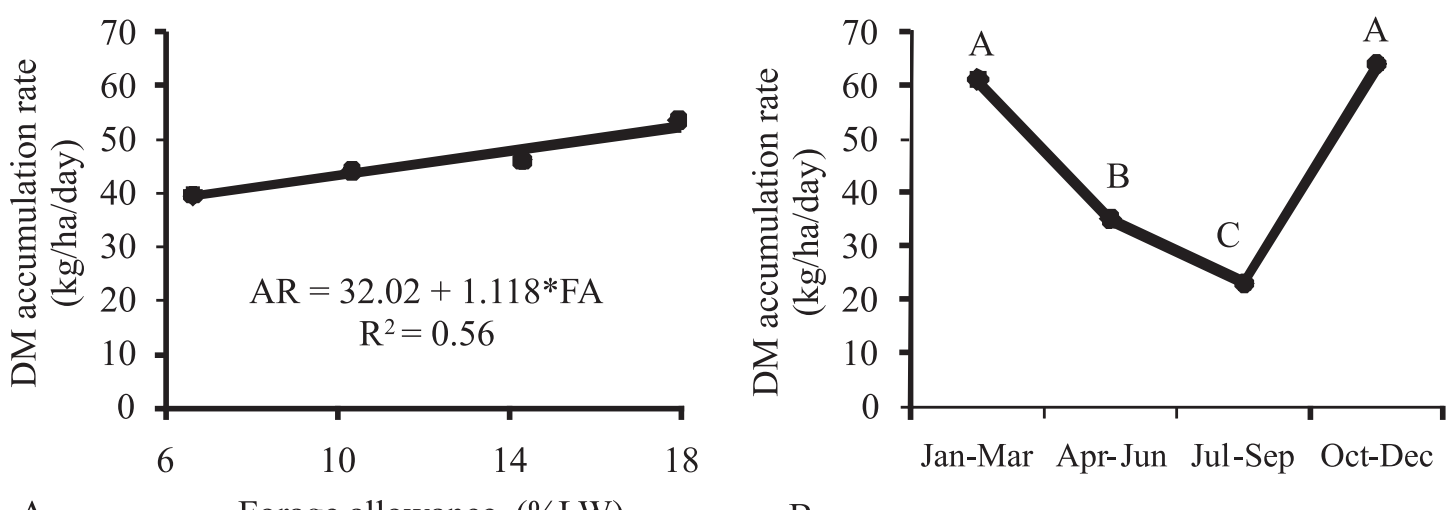

A

Forage allowance $(\% \mathrm{LW})$

B

* Significant by the $\mathrm{F}$ test at the $5 \%$ level. Periods with means followed by the same letters are not different (P $>0.05)$ by the Tukey test.

Figure 1 - Variation in DM accumulation rates as a function of forage allowance (A) and period of the year (B). 
There was no interaction $(\mathrm{P}>0.05)$ between forage allowance and period of the year for defoliation intensity, grazing depth and grazed horizon in the mixed pasture of marandugrass, tropical kudzu and forage peanut. Both the defoliation intensity and grazing depth were higher in the two lowest forage allowance levels, with data adjusting to a quadratic model (Figures 2A and 2C). There was also seasonal variation $(\mathrm{P}<0.05)$, with higher defoliation intensity during the rainy season (October to March); intermediary in April-June and lower during the July-September period (Figures 2B and 2D). Seasonal variation in grazing depth differed from that observed for defoliation intensity, especially in relation to the values obtained in the JanuaryMarch period (Figure 2D), which were higher due to plant lodging that occurred in the first two stocking cycles. This was a consequence of excessive sward height $(78 \mathrm{~cm})$ at the beginning of the experimental period (Andrade et al., 2012). This indicates that defoliation intensity was a more efficient indicator of the relative pasture utilization efficiency for the conditions of this study.

Sward defoliation intensity can be influenced by stocking density (Lemaire \& Chapman, 1996) and also by sward structure, since a higher proportion of pseudostem and senescent material affects negatively the grazing

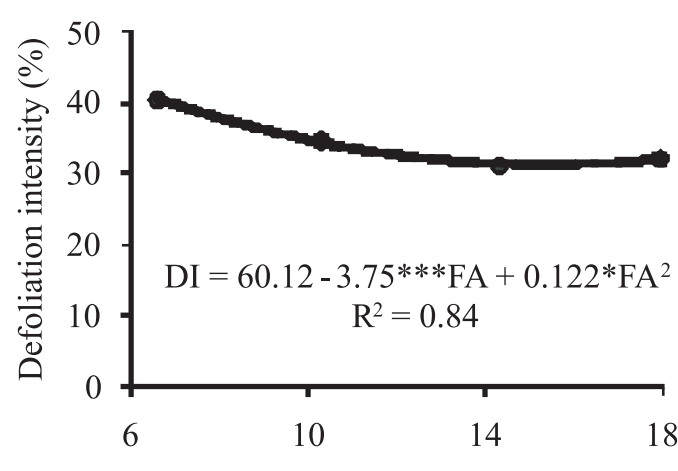

A Forage allowance $(\% \mathrm{LW})$
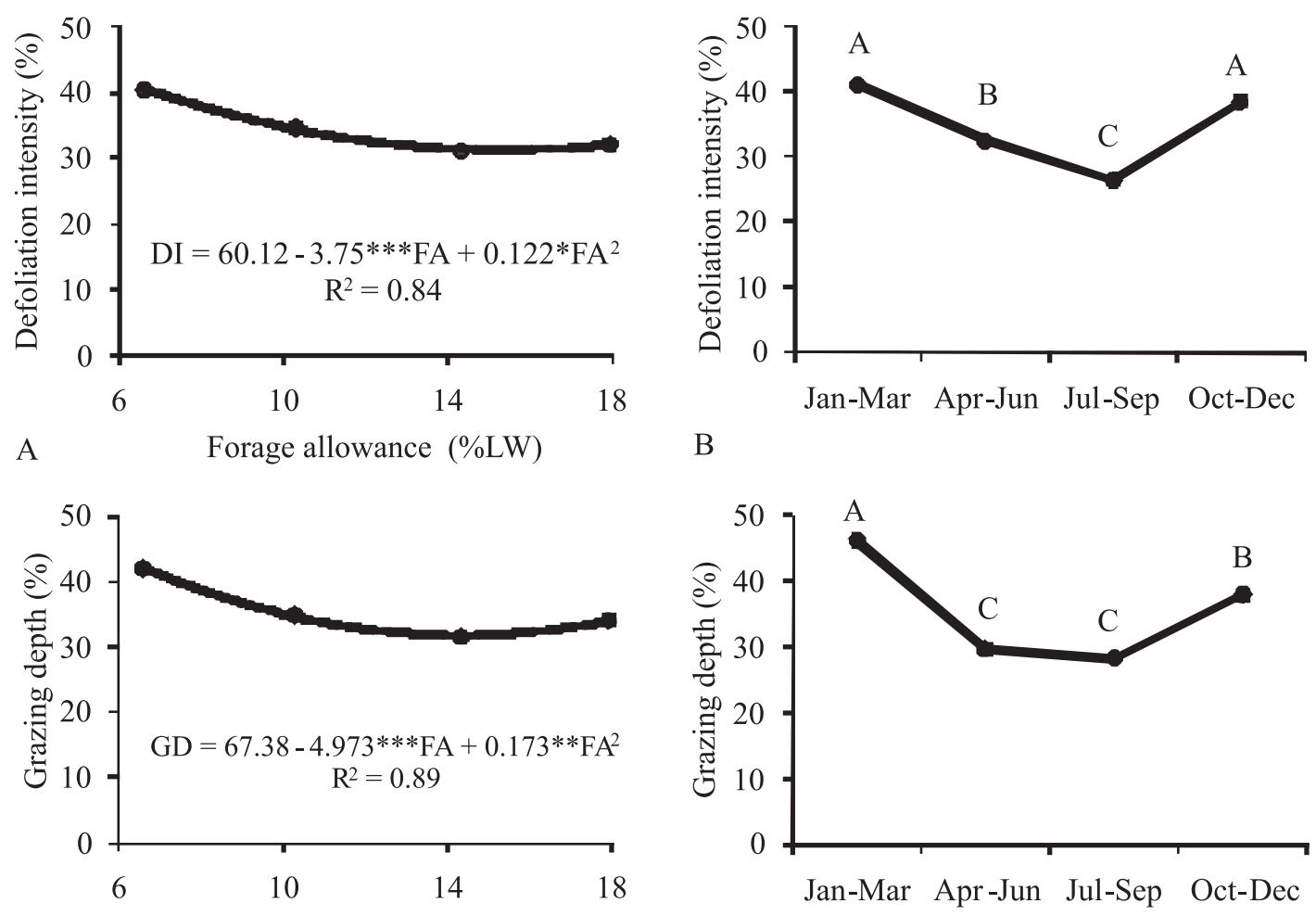

C Forage allowance $(\% \mathrm{LW})$

B

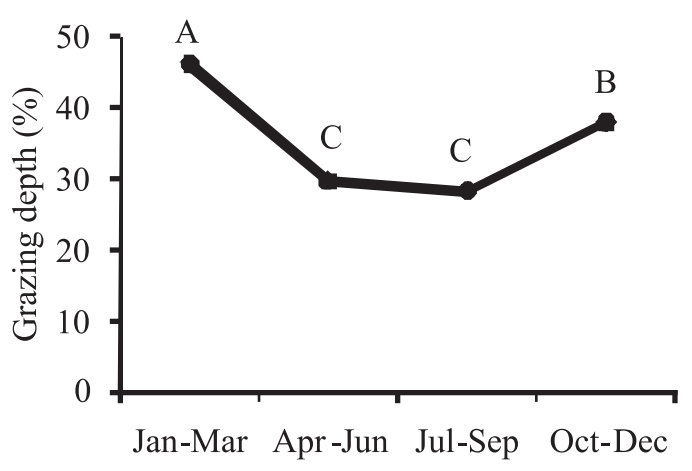

$\mathrm{D}$
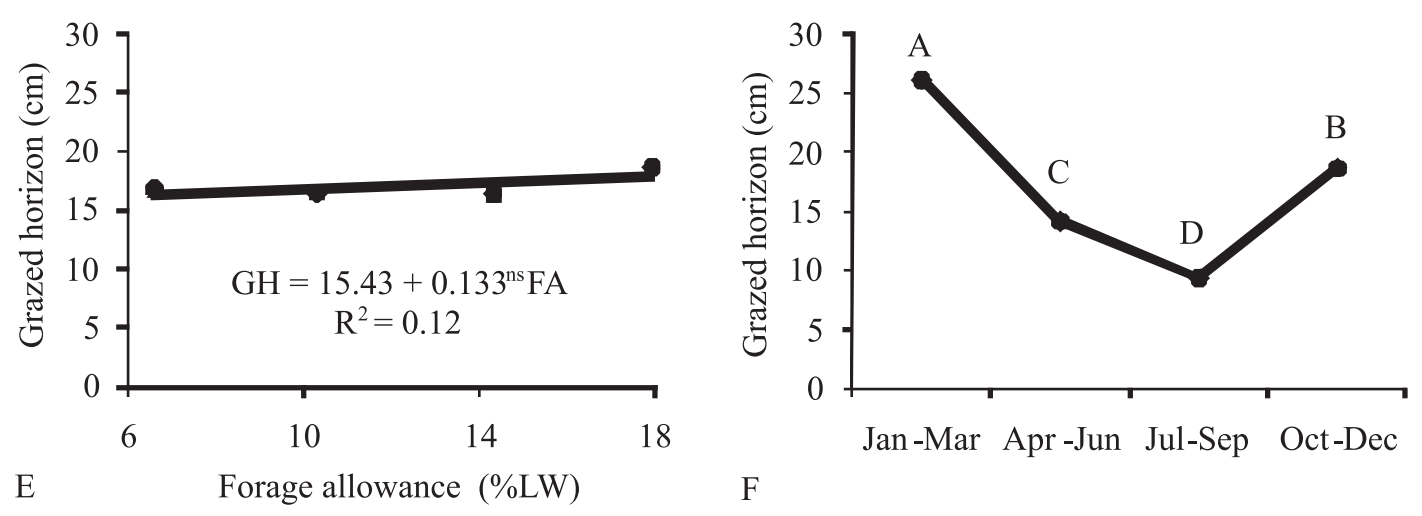

$\mathrm{LW}=$ Live weight; $\mathrm{FA}=$ forage allowance; ${ }^{\mathrm{ns}}, *, * *, * * *$ Non significant $\mathrm{F}$ test at the $5 \%$ level, and significant at $5 \%, 1 \%$ and $0.1 \%$, respectively. Means with the same letters, for each variable, are not different $(\mathrm{P}>0.05)$ by the Tukey test.

Figure 2 - Variation in defoliation intensity, grazing depth and grazed horizon as a function of forage allowance and period of the year. 
behavior of ruminants, limiting forage intake (Brâncio, 2000; Sollenberger \& Burns, 2001). Therefore, the decrease in defoliation intensity during the driest period of the year seems to have been caused by a combination of these two factors, since there was a lower proportion of leaves in the sward during the period of lower growth, when lower stocking densities were also used due to a reduction in pregrazing forage mass (Andrade et al., 2012).

Grazed horizon $(\mathrm{cm})$ represents the superior layer of the sward that is removed by the grazing animals during the stocking period. In the present study, grazed horizon was similar (mean of $17.1 \mathrm{~cm}$ ) in the different treatments (Figure $2 \mathrm{E}$ ), an expected result in swards managed under different forage allowances, since higher swards are less intensively grazed and lower swards are more intensively grazed (Andrade et al., 2006a). Grazed horizon presented seasonal variation (Figure 2F) similar to pre-grazing sward height (Andrade et al., 2012), with high correlation between the two variables $(r=0.96)$, a result similar to that reported by Brâncio et al. (2003), evaluating three P. maximum cultivars and by Andrade et al. (2006a) in a study with a mixed pasture of massaigrass and forage peanut. Grazed horizon was bigger during the January-March period (mean of $26 \mathrm{~cm}$ ), as a result of plant lodging, decreasing to $14 \mathrm{~cm}$ in the AprilJune period, and to only $9 \mathrm{~cm}$ in the July-September period. With the increasing rainfall during the October-December period, there was also an increase in grazed horizon (average of $19 \mathrm{~cm}$ ). This was due to the greater availability of green leaves in the upper layer of the sward during periods of higher pasture growth.

The main goal of this study is to recommend sward management targets, defined based on sward conditions, in order to provide a support decision tool to increase utilization efficiency of mixed pastures of marandugrass with tropical kudzu and forage peanut in the Western Brazilian Amazon. The results of this study fully confirm previous information available in the literature regarding the differences in these legume species, in relation to response to grazing, which suggests that it would be very difficult to establish a unique grazing management strategy in order to favor the maintenance of the productive capacity of these forage legumes in a mixed grass-legume pasture.

It was not possible to determine a sward condition which favored the maintenance of the productive capacity of tropical kudzu in a mixed pasture with marandugrass under rotational stocking. This legume was sensitive to all forage allowance levels used and its contribution to the sward botanical composition presented strong reduction during the experimental period, especially during JulySeptember (Andrade et al., 2012). There is need for more studies using a broader combination of management factors and a more detailed investigation of the processes the affect persistence of tropical kudzu, in order to be able to recommend sward management strategies for this grasslegume association.

Productive capacity of forage peanut was favored by sward conditions resulting from the use of lower forage allowance levels. In these conditions, the legume had greater ability to compete with marandugrass, increasing its forage mass along the experimental period (Table 1). Although sward condition established in the lowest forage allowance level (6.6\% of live weight) was the most favorable to forage peanut, grass defoliation intensity seems to have been too high, at the risk of also favoring an increase of percentage weeds, thus decreasing pasture productivity. Conversely, pastures maintained with forage allowance levels of 14.3 and $17.9 \%$ LW presented higher productivity, although being used with less efficiency. Also, sward conditions established under these forage allowance levels restricted the growth of forage peanut in comparison with the other treatments. This result is in agreement with the literature (Hernandez et al., 1995; Ibrahim \& Mannetje, 1998) and corroborates the statement of Hodgson \& Silva (2002), that the definition of grazing management strategies for grassforage peanut pastures should aim at balancing the advantage of higher productivity of pastures maintained under lower grazing pressures, with the advantage of a higher proportion of the legume in the pastures under higher grazing pressures.

Therefore, sward condition resulting from forage allowance of $10.3 \%$ live weight (LW) was the one that provided high production capacity of forage peanut with good pasture productivity and utilization (Table 1). This condition also contributed to maintain a low incidence of weeds (Table 1), an important factor for pasture production in the Amazon region where there is a high biotic pressure caused by the different weed species (Dias-Filho, 2007). This was considered the critical (ideal) condition for mixed pastures of marandugrass and A. pintoi cv. Mandobi. Therefore, sward management targets were established aiming at maintaining pre- and post-grazing sward height close to this condition.

The following sward targets can be recommended in order to guide rotational stocking management of mixed pastures of marandugrass and forage peanut in the environmental conditions of the Western Brazilian Amazon: pre-grazing height ranging from $30-35 \mathrm{~cm}$ (June to September) to $45-50 \mathrm{~cm}$ (October to May), and post-grazing height of 20-25 cm (June to September) to 25-30 cm (October to May). Suggested sward target values for the period of lower 
pasture growth (June to September) were different from those established for the remainder of the year, especially in the pre-grazing condition. It was observed that even reducing the stocking rates and increasing the rest period, sward condition remained with lower height and forage mass in this period due to lower pasture growth. Therefore, due to climatic variation among years, it is important to have greater flexibility in the use of sward targets established for the pre-grazing condition, especially during the transition months between the dry and rainy seasons (May/June and September/October).

Studies in grass pastures show that forage allowances between 6 and 11\% LW assure good animal production levels, although there is variation between studies in relation to the type of forage mass offered, if expressed as total, green or leaf dry mass (Adjei et al., 1980; Hodgson, 1990; Almeida et al., 2000a, b; Barbosa et al., 2001; Gomide et al., 2001; Penati, 2002). Therefore, although animal production was not measured in the present study, the literature results suggest that the recommended sward management targets, based on forage allowance of $10.3 \% \mathrm{LW}$, should assure good levels of animal production in mixed pastures of marandugrass with forage peanut.

Hodgson (1990) defined critical sward height as that in which forage consumption or animal performance are close to the maximum. According to this author, results of studies with perennial ryegrass and white clover have shown that residual height under rotational stocking is equivalent, approximately, to the critical sward height under continuous stocking. If this relation is also true for mixed pastures of marandugrass with forage peanut, its management under continuous stocking should be based on targets of sward heights between $20-25 \mathrm{~cm}$, during the dry season, and 25$30 \mathrm{~cm}$, during the rainy season in the Western Amazon. Some studies show that pure marandugrass pastures could be managed under continuous stocking with mean sward height between 20 and $40 \mathrm{~cm}$, without much variation in relation to pasture productivity and forage consumption by the grazing animals (Lupinacci, 2002; Sarmento, 2003; Flores et al., 2008). The similarity between these sward targets suggests that this relation could also be true for mixed pastures of marandugrass with forage peanut. However, those sward targets should only be recommended after the studies to confirm its usefulness are carried out.

According to Hodgson (1990), grazing management based on sward targets should be associated with strategies to deal with the seasonality of pasture carrying capacity. In this study, pasture carrying capacity was determined by the stocking rate resulting of the forage allowance that established the ideal (critical) sward condition of the mixed pasture. For the year 2003, annual carrying capacity of this pasture was $2.5 \mathrm{AU} / \mathrm{ha}$, with $3.1 \mathrm{AU} / \mathrm{ha}$ as the average of the rainy season and 1.8 AU/ha as the average of the dry season. In another study carried out in the State of Acre, in

Table 1 - Summary of sward condition (height and forage mass), botanical composition, productivity and defoliation intensity of a mixed pasture of marandugrass with forage peanut and tropical kudzu, according the forage allowance levels

\begin{tabular}{|c|c|c|c|c|}
\hline \multirow[t]{2}{*}{ Parameter } & \multicolumn{4}{|c|}{ Forage allowance (\%LW) } \\
\hline & 6.6 & 10.3 & 14.3 & 17.9 \\
\hline \multicolumn{5}{|l|}{ Sward height $(\mathrm{cm})^{1}$} \\
\hline Pre-grazing & $25-39$ & $34-48$ & $36-54$ & $38-58$ \\
\hline Post-grazing & $17-21$ & $23-29$ & $28-35$ & $30-40$ \\
\hline \multicolumn{5}{|l|}{ Forage mass ( $\mathrm{t} / \mathrm{ha}$ of $\mathrm{DM})$} \\
\hline Pre-grazing 1 & $2.2-3.2$ & $3.1-3.9$ & $3.3-4.4$ & $3.6-4.7$ \\
\hline Post-grazing 1 & $1.6-1.7$ & $2.2-2.4$ & $2.7-2.8$ & $2.8-3.0$ \\
\hline Marandugrass $^{2}$ & 2.1 & 2.6 & 3.6 & 3.8 \\
\hline Forage peanut ${ }^{2}$ & 0.66 & 0.57 & 0.37 & 0.18 \\
\hline Tropical kudzu² & 0.26 & 0.53 & 0.31 & 0.69 \\
\hline \multicolumn{5}{|l|}{ Botanical composition $(\%)^{2}$} \\
\hline Marandugrass & 63.9 & 68.6 & 81.9 & 79.7 \\
\hline Forage peanut & 21.1 & 15.2 & 8.4 & 3.8 \\
\hline Tropical kudzu & 8.6 & 14.0 & 6.9 & 14.7 \\
\hline Weeds & 6.4 & 2.1 & 2.8 & 1.8 \\
\hline \multicolumn{5}{|l|}{ Productivity and utilization } \\
\hline Annual DM production (t/ha) & 14.4 & 16.2 & 16.7 & 19.4 \\
\hline Mean stocking rate (AU/ha) & 2.9 & 2.5 & 2.0 & 1.8 \\
\hline Defoliation intensity (\%) & 41 & 35 & 31 & 32 \\
\hline
\end{tabular}

${ }^{1}$ Average sward condition during the driest (July-September) and rainiest periods (October-December), respectively.

2 Pre-grazing botanical composition in October-December 2003.

$\mathrm{LW}=$ live weight.

Source: Data compiled from Andrade et al. (2012) and this paper. 
a mixed pasture of massaigrass and forage peanut (Andrade et al., 2006b), carrying capacity was similar in the dry season (1.8 AU/ha) and 20\% higher in the rainy season (3.6 AU/ha).

Pasture carrying capacity is affected by many factors such as climate, soil, management and potential productivity of forage species (Gomide et al., 2001). Therefore, it is important to emphasize that the values obtained are specific for the year 2003, and for the soil, paddock size and grazing management of this study; and should not be directly extrapolated for other pastures in the Region. However, the analysis of the seasonal variation in pasture carrying capacity can be used in planning pasture-based animal production systems in the region, aiming at improving the feed budget on farms.

As expected, seasonal variation of pasture carrying capacity followed a similar trend as that presented by pasture productivity and rainfall (Figure 3). However, there was a better association with DM accumulation rates $(r=0.92)$ than with rainfall $(r=0.72)$.
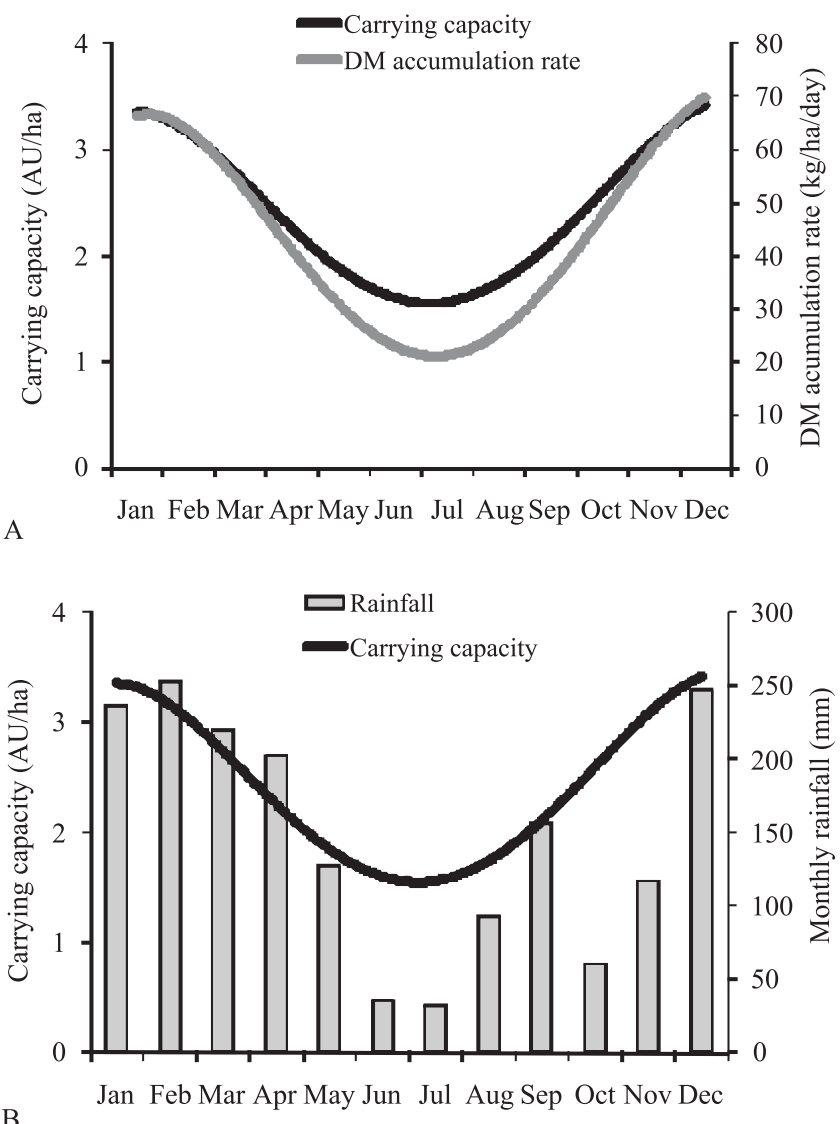

Figure 3 - Seasonal variation of carrying capacity and DM accumulation rates of mixed pastures of marandugrass, forage peanut and tropical kudzu (A) and of monthly rainfall (B) at Rio Branco, Acre, through the year 2003.
The association between carrying capacity and pasture productivity was higher during the period with climatic condition more favorable for pasture growth. With the onset of the dry season, the consequent reduction in carrying capacity was less evident than that observed for pasture productivity, indicating a certain degree of buffering provided from the accumulated forage mass. Overall, carrying capacity during the dry season was equivalent to $58 \%$ of that estimated for the rainy season.

Data of carrying capacity and DM accumulation rate, in each stocking cycle, were submitted to regression analysis, resulting in a well-fitted linear equation (Figure 4), indicating that DM accumulation rate accounted for $84 \%$ of the variation in carrying capacity.

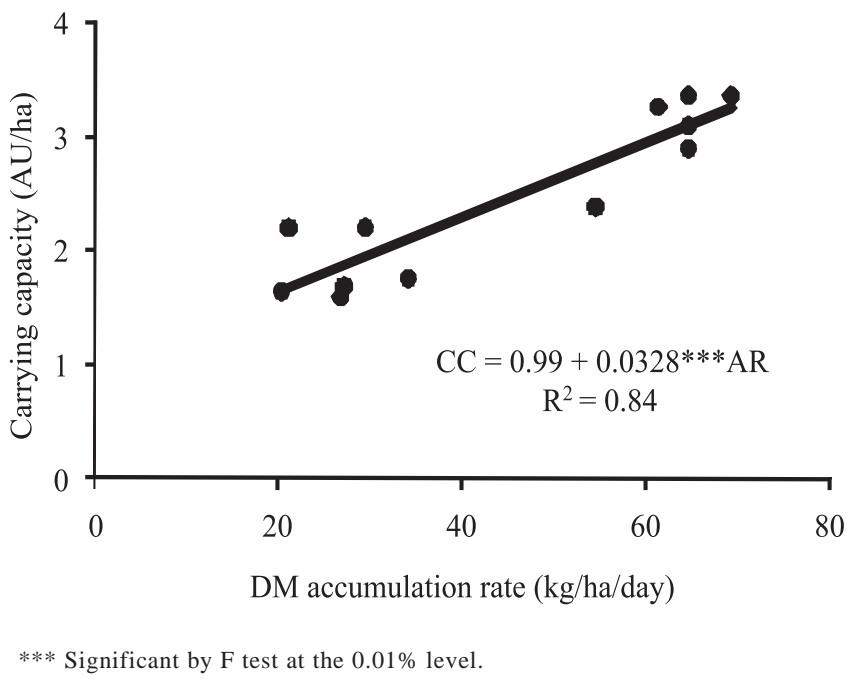

Figure 4 - Relation between carrying capacity and DMaccumulation rate in the rotationally stocked mixed pasture of marandugrass, forage peanut and tropical kudzu during the year 2003.

\section{Conclusions}

In the environmental conditions of the Western Amazon, the following sward management targets are recommended for a mixed pasture of marandugrass with forage peanut under rotational stocking: pre-grazing sward height from 30-35 cm (June-September) to $45-50 \mathrm{~cm}$ (October-May), and post-grazing sward height from 20-25 cm (June-September) to 25-30 cm (October-May). More studies are needed in order to define an adequate grazing management strategy for mixed pastures of marandugrass with tropical kudzu. 


\section{References}

ADJEI, M.B.; MISLEVY, P.; WARD, C.Y. Response of tropical grasses to stocking rate. Agronomy Journal, v.72, p.863-868, 1980.

ALMEIDA, E.X.; MARASCHIN, G.E.; HARTHMANN, O.E.L. et al. Oferta de forragem de capim-elefante anão 'Mott' e a dinâmica da pastagem. Revista Brasileira de Zootecnia, v.29, n.5, p.1281-1287, 2000a.

ALMEIDA, E.X.; MARASCHIN, G.E.; HARTHMANN, O.E.L. et al. Oferta de forragem de capim-elefante anão 'Mott' e o rendimento animal. Revista Brasileira de Zootecnia, v.29, n.5, p.1288-1295, 2000b.

ANDRADE, C.M.S.; GARCIA, R.; VALENTIM, J.F. et al. Grazing management strategies for massaigrass-forage peanut pastures. 2. Productivity, utilization and swart structure. Revista Brasileira de Zootecnia, v.35, n.2, p.343-351, 2006a.

ANDRADE, C.M.S.; GARCIA, R.; VALENTIM, J.F. et al. Grazing management strategies for massaigrass-forage peanut pastures. 3. Definition of award targets and carrying capacity. Revista Brasileira de Zootecnia, v.35, n.2, p.352-357, 2006b.

ANDRADE, C.M.S.; GARCIA, R.; VALENTIM, J.F. et al. Dynamics of sward condition and botanical composition of mixed pastures of marandugrass, forage peanut and tropical kudzu. Revista Brasileira de Zootecnia, v.41, n.3, p.501-511, 2012.

BARBOSA, M.A.A.F.; NASCIMENTO JÚNIOR, D.; CECATO, U. et al. Desempenho de novilhos em capim tanzânia com diferentes ofertas de forragem. In: REUNIÃO ANUAL DA SOCIEDADE BRASILEIRA DE ZOOTECNIA, 38., 2001, Piracicaba. Anais... Piracicaba: SBZ, 2001. (CD-ROM).

BRÂNCIO, P.A. Comportamento animal e estimativas de consumo por bovinos em pastagens de Panicum maximum Jacq. (cultivares Tanzânia, Mombaça e Massai). 2000. $278 f$. Tese (Doutorado em Zootecnia) - Universidade Federal de Viçosa, Viçosa, MG.

BRÂNCIO, P.A.; EUCLIDES, V.P.B.; NASCIMENTO JÚNIOR, D. et al. Avaliação de três cultivares de Panicum maximum Jacq. sob pastejo: disponibilidade de forragem, altura do resíduo pós-pastejo e participação de folhas, colmos e material morto. Revista Brasileira de Zootecnia, v.32, n.1, p.55-63, 2003.

CRUZ, P.A.; SINOQUET, H. Competition for light and nitrogen during a regrowth cycle in a tropical forage mixture. Field Crops Research, v.36, p.21-30, 1994.

DIAS-FILHO, M.B. Degradação de pastagens: processos, causas e estratégias de recuperação. 3.ed. Belém: Embrapa Amazônia Oriental, 2007. 190p.

FISHER, M.J.; RAO, I.M.; THOMAS, R.J. et al. Grasslands in the well-watered tropical lowlands. In: HODGSON, J.; ILLIUS, A.W. (Eds.) The Ecology and management of grazing systems. Wallingford: CAB International, 1996. p.393-425.

FLORES, R.S.; EUCLIDES, V.P.B.; ABRÃO, M.P.C. et al. Desempenho animal, produção de forragem e características estruturais dos capins marandu e xaraés submetidos a intensidades de pastejo. Revista Brasileira de Zootecnia, v.37, n.8, p.1355-1365, 2008.

GOMIDE, J.A.; WENDLING. I.J.; BRAS, S.P. et al. Consumo e produção de leite de vacas mestiças em pastagem de Brachiaria decumbens manejada sob duas ofertas diárias de forragem. Revista Brasileira de Zootecnia, v.30, n.4, p.1194-1199, 2001.

HERNANDEZ, M.; ARGEL, P.J.; IBRAHIM, M.A. et al. Pasture production, diet selection and liveweight gains of cattle grazing Brachiaria brizantha with or without Arachis pintoi at two stocking rates in the Atlantic Zone of Costa Rica. Tropical Grasslands, v.29, p.134-141, 1995.
HODGSON, J. Grazing management: science into practice. Harlow: Longman Scientific \& Technical, 1990. 203p.

HODGSON, J.; SILVA, S.C. Sustainability of grazing systems: goals, concepts and methods. In: LEMAIRE, G.; HODGSON, J.; MORAES, A. et al. (Eds.) Grassland ecophysiology and grazing ecology. Wallingford: CAB International, 2000. p.1-13.

HODGSON, J.; SILVA, S.C. Options in tropical pasture management. In: REUNIÃO ANUAL DA SOCIEDADE BRASILEIRA DE ZOOTECNIA, 39., 2002, Recife. Anais... Recife: SBZ, 2002. p.180-202.

IBRAHIM, M.A.; MANNETJE, L.'t. Compatibility, persistence and productivity of grass-legume mixtures in the humid tropics of Costa Rica. 1. Dry matter yield, nitrogen yield and botanical composition. Tropical Grasslands, v.32, n.2, p.96-104, 1998.

LASCANO, C.E. Selective grazing on grass-legume mixtures in tropical pastures. In: LEMAIRE, G.; HODGSON, J.; MORAES, A. et al. (Eds.) Grassland ecophysiology and grazing ecology. Wallingford: CAB International, 2000. p.249-263.

LEMAIRE, G.; CHAPMAN, D. Tissue flows in grazed plant communities. In: HODGSON, J.; ILLIUS, A.W. (Eds.) The ecology and management of grazing systems. Wallingford: CAB International, 1996. p.3-36.

LUPINACCI, A.V. Reservas orgânicas, índice de área foliar e produção de forragem em Brachiaria brizantha cv. Marandu submetida a intensidades de pastejo por bovinos de corte. 2002. 160f. Dissertação (Mestrado em Agronomia) - Escola Superior de Agricultura Luiz de Queiroz - Universidade de São Paulo, Piracicaba.

MATTHEWS, P.N.P.; HARRINGTON, K.C.; HAMPTON, J.G. Management of grazing systems. In: WHITE, J.; HODGSON, J. (Eds.) New Zealand pasture and crop science. Auckland: Oxford University Press, 1999. p.153-174.

PENATI, M.A. Estudo do desempenho animal e produção do capim Tanzânia (Panicum maximum Jacq.) em um sistema rotacionado de pastejo sob irrigação em três níveis de resíduo pós-pastejo. 2002. 117f. Tese (Doutorado em Agronomia) - Escola Superior de Agricultura Luiz de Queiroz Universidade de São Paulo, Piracicaba.

PEREIRA, J.M. Leguminosas forrageiras em sistemas de produção de ruminantes: onde estamos? para onde vamos? In: SIMPÓSIO SOBRE MANEJO ESTRATÉGICO DE PASTAGENS, 1., 2002, Viçosa, MG. Anais... Viçosa, MG: DZO/UFV, 2002. p.109-147.

SARMENTO, D.O.L. Comportamento ingestivo de bovinos em pastos de capim marandu submetidos a regimes de lotação contínua. 2003. 76f. Dissertação (Mestrado em Agronomia) - Escola Superior de Agricultura Luiz de Queiroz Universidade de São Paulo, Piracicaba.

SILVA, M.A. Alturas de pastejo em pastagem consorciada de Brachiaria brizantha e Arachis pintoi. 2008. 102f. Tese (Doutorado em Ciências) - Universidade Federal do Paraná, Curitiba.

SOLLENBERGER, L.E.; BURNS, J.C. Canopy characteristics, ingestive behaviour and herbage intake in cultivated tropical grasslands. In: INTERNATIONAL GRASSLAND CONGRESS, 19., 2001, São Pedro. Proceedings... São Paulo: SBZ, 2001. (1 CD-ROM).

SPAIN, J.M. O uso de leguminosas herbáceas nas pastagens tropicais. In: PEIXOTO, A.M.; MOURA, J.C.; FARIA, V.P. (Eds.) Plantas forrageiras de pastagens. Piracicaba: FEALQ, 1995. p.275-299.

THOMAS, R.J. Roles of legumes in providing $\mathrm{N}$ for sustainable tropical pasture systems. Plant and Soil, v.174, n.1-2, p.103-118, 1995.

VALENTIM, J.F.; ANDRADE, C.M.S. Forage peanut (Arachis pintoi): a high yielding and high quality tropical legume for sustainable cattle production systems in the Western Brazilian Amazon. Tropical Grasslands, v.39, n.4, p.222, 2005a. 
VALENTIM, J.F.; ANDRADE, C.M.S. Tropical kudzu (Pueraria phaseoloides): successful adoption in sustainable catte production systems in the Western Brazilian amazon. Tropical Grasslands, v.39, n.4, p.221, 2005b.

VALENTIM, J.F.; CARNEIRO, J.C. Pueraria phaseoloides e Calopogonium mucunoides. In: SIMPÓSIO SOBRE MANEJO
DA PASTAGEM, 17., 2001, Piracicaba. Anais... Piracicaba: FEALQ, 2001. 2.ed. p.427-458.

VAlentim, J.F.; CARneiro, J.C.; SAleS, M.F.L. Amendoim forrageiro cv. Belmonte: leguminosa para a diversificação das pastagens e conservação do solo no Acre. Rio Branco: Embrapa Acre, 2001. 18p. (Circular Técnica, 43). 